\title{
Biological Aspects of the Critically Endangered Fish, Labeo boga in the Ganges River, Northwestern Bangladesh
}

(Aspek Biologi Ikan Terancam Kritikal, Labeo boga di dalam Sungai Ganges, Barat Laut Bangladesh)

\author{
Md. Yeamin Hossain*, Sharmin Jahan, Md. Abu SaYed Jewel, Md. MosadDeQur Rahman, \\ MST. MONIRA KHATUN \& SALEHA JASMINE
}

\begin{abstract}
The present study reports the first complete and inclusive description of some biological parameters including length-

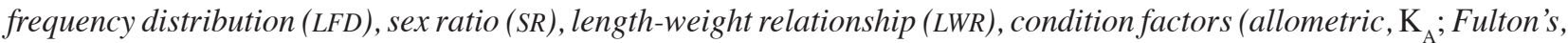
$\mathrm{K}_{\mathrm{F}}$; relative, $\mathrm{K}_{\mathrm{R}}$ and relative weight, $\mathrm{W}_{\mathrm{R}}$ ) and form factor $\left(\mathrm{a}_{3.0}\right)$ of Labeo boga in the Ganges River, northwestern Bangladesh. Sampling was conducted using traditional fishing gears during April 2011 to March 2012. For each specimen, total length (TL) was measured to the nearest $0.01 \mathrm{~cm}$ using digital slide calipers and total body weight (BW) was measured using an electronic balance with $0.01 \mathrm{~g}$ accuracy. The LWR was calculated using the expression: $\mathrm{W}=\mathrm{a} \mathrm{L}^{\mathrm{b}}$, where $\mathrm{W}$ is the $B W$ and $\mathrm{L}$ is the TL. A total of 211 specimens ranging from 9.78-27.50 cm TL and 10.00 to $276.10 \mathrm{~g} \mathrm{BW}$ were studied. $B \mathrm{~W}$ of females was significantly higher than that of males (Mann-Whitney U-test, $\mathrm{p}>0.001$ ). However the overall sex ratio did not differ significantly from the expected value of $1: 1\left(\chi^{2}=0.12, \mathrm{p}<0.05\right)$. The calculated $\mathrm{b}$ for the LWR indicated isometric growth (» 3.00) in males, females and combined gender and there were significant differences in the intercepts but not in the slopes between the sexes of $\mathrm{L}$. boga in the Ganges River. $\mathrm{K}_{\mathrm{F}}$ of females was significantly higher than that for males $(\mathrm{p}<0.001)$. In addition, the Wilcoxon signed rank test showed that the $\mathrm{W}_{\mathrm{R}}$ did not differ from 100 for males and females in this study indicating good condition of habitat for L. boga. The results of this study would be an effective tool for fishery specialists to initiate early management strategies and regulations for the sustainable management of the remaining stocks of this species within the Padma River and surrounding ecosystems.
\end{abstract}

Keywords: Condition; conservation; Ganges; Labeo boga; Length-weight relationship

\section{ABSTRAK}

Kajian ini melaporkan huraian lengkap dan terangkum pertama beberapa parameter biologi termasuk taburan panjang frekuensi (LFD), nisbah jantina (SR) hubungan panjang-berat (LWR), faktor keadaan (alometrik, $\mathrm{K}_{\mathrm{A}}$; Fulton, $\mathrm{K}_{\mathrm{F}}$; relatif, $\mathrm{K}_{\mathrm{R}}$ dan berat relatif, $\mathrm{W}_{\mathrm{R}}$ ) serta faktor bentuk $\left(\mathrm{a}_{3.0}\right)$ Labeo boga di dalam Ganges Sungai, Barat Laut Bangladesh. Pensampelan dijalankan menggunakan peralatan tradisi menangkap ikan sepanjang April 2011 hingga Mac 2012. Bagi setiap spesimen, jumlah panjang (TL) dikira ke $0.01 \mathrm{~cm}$ terdekat menggunakan slaid angkup digital dan berat keseluruhan badan (BW) diukur menggunakan penimbang elektronik dengan $0.01 \mathrm{~g}$ ketepatan. LWR dikira menggunakan ungkapan: $\mathrm{W}=\mathrm{a} \mathrm{L}^{\mathrm{b}}$, dengan $\mathrm{W}$ adalah $B W$ dan $\mathrm{L}$ adalah TL. Sebanyak 211 spesimen antara 9.78-27.50 cm TL dan $10.00 \mathrm{ke} 276.10 \mathrm{~g}$ $B$ W telah dikaji. $B$ W betina adalah lebih tinggi daripada jantan (U-ujian Mann-Whitney, $>>0.001$ ), walau bagaimanapun, nisbah jantina keseluruhan pula tidak berbeza secara signifikan daripada nilai dijangka $1: 1\left(\chi^{2}=0.12, \mathrm{p}<0.05\right)$. Kiraan b untuk LWR menunjukkan pertumbuhan isometrik ("3.00) pada jantan, betina dan gabungan jantina serta terdapat perbezaan signifikan dalam pintasan tersebut tetapi tidak di cerun antara jantina L. boga di dalam Sungai Ganges. $\mathrm{K}_{\mathrm{F}}$ betina adalah lebih tinggi daripada jantan $(\mathrm{p}<0.001)$. Disamping itu, pangkat uji bertanda Wilcoxon menunjukkan bahawa $\mathrm{W}_{\mathrm{R}}$ tidak berbeza daripada 100 untuk jantan dan betina dalam kajian ini dan menunjukkan keadaan yang baik untuk habitat L. boga. Keputusan kajian ini boleh menjadi alat yang berkesan untuk pakar perikanan memulakan strategi awal pengurusan dan peraturan bagi pengurusan yang mampan untuk stok spesies ini di dalam Sungai Padma dan ekosistem persekitaran.

Kata kunci: Ganges; keadaan; Labeo boga; hubungan panjang-berat; pemuliharaan

\section{INTRODUCTION}

Bangladesh is rich in fish diversity which is now under threat due to over exploitation, habitat loss, ecological changes to fish habitat and some other divergent reasons thus 54 freshwater fish species has been categorized as threaten to extinction in Bangladeshi waters (IUCN
Bangladesh 2000). Conservation of threatened to extinction fish species is a vital topic in modern scientists' society (Hossain et al. 2013c). However, proper understanding about the relative growths and condition factors of a species forms the base for the execution of appropriate management strategies for protecting 
the critically endangered fish like Labeo boga (IUCN Bangladesh 2000).

The boga lebeo, Labeo boga (Hamilton 1822) belongs to the family Cyprinidae of the order Cypriniformes is a commercially important indigenous fish species of Bangladesh. The L. boga is widely distributed in the big rivers and their tributaries, above tidal influence, estuaries and ponds of Bangladesh, India, Myanmar, Nepal and Pakistan (Dahanukar 2010; IUCN Bangladesh 2000; Menon 1999). L. boga feeds on rotten plant, algae and plankton (Rahman 2005). The L. boga is highly priced fish preferred by the consumer of all classes. However, due to over exploitation, siltation, habitat loss and other ecological changes to its habitat, the natural population of L. boga in Bangladeshi waters is decreasing rapidly and is subsequently categorized as critically endangered (Dahanukar 2010; IUCN Bangladesh 2000).

Length-weight relationships (LWRs), condition- and form factors of threatened fishes are the most important biological parameters for management and conservation of natural populations (Hossain et al. 2013a; 2013b; 2012a; 2009a). LWRs are effective in fishery assessments for predicting length distributions into weights for biomass estimates (Gerritsen \& McGrath 2007; Hossain et al. 2009b) and a cost-effective substitute to direct, fieldbased weight measurements that can be time-consuming (Koutrakis \& Tsikliras 2003). In addition, the LWR is useful in assessing the well-being of the individuals and in determining possible differences among different stocks of the same species (King 2007). Furthermore, the condition factors of threatened fishes are the most important biological parameter which provide information on condition of fish species and the entire community and is of high significance for management and conservation of natural populations (Hossain et al. 2014; 2012a; 2012b). However, no comprehensive study on these aspects of $L$. boga is available from the Padma River (except Hossain et al. 2014). Therefore, the objectives of this study were to describe the length-frequency distribution (LFD); sex ratio (SR); length-weight relationships (LWRs), condition and form factors of L. boga in the lower part Ganges River, NW Bangladesh.

\section{MATERIALS AND METHODS}

\section{STUDY SITE AND FISH SAMPLING}

Sampling was conducted in the lower part of the Ganges (also known as Padma River in Bangladesh) River, northwestern Bangladesh. Samples of L. boga were collected during daytime on a seasonal basis from different fishermen catch landed at Jahaj ghat to Godagari, Rajshahi (Padma River: 2446'N; 88³2'E) over a period of one year from April 2011 to March 2012. L. boga were caught by the traditional fishing gears including cast net (jhaki jal), square lift net (tar jal) and conical trap (dughair). Samples were immediately preserved with ice in the fish landing area and fixed with 5\% formalin on arrival at the laboratory, Department of Fisheries, University of Rajshahi, Bangladesh. For each individual, total length (TL), standard length (SL) and fork length (FL) were measured to the nearest $0.01 \mathrm{~cm}$ using digital slide calipers (Mitutoyo, CD-15PS; Mitutoyo Corporation, Tokyo, Japan) and whole body weight (BW) was taken on a digital balance (Shimadzu, EB-430DW; Shimadzu Seisakusho, Tokyo, Japan) with $0.01 \mathrm{~g}$ accuracy.

\section{LENGTH-WEIGHT RELATIONSHIPS}

The LWR was determined according to the allometric equation $W=a L^{b}$, where $W$ and $L$ are the BW (g) and TL (cm), respectively. Parameters $a$ and $b$ were estimated by linear regression analysis based on natural logarithms $\ln (W)=\ln (a)+b \ln (L)$. In addition, 95\% confidence limits of $b$ and the coefficient of determination $r^{2}$ were estimated. According to Froese (2006), prior to the regression analysis of $\ln$ BW on $\ln \mathrm{TL}, \ln -\ln$ plots of length and weight values were performed for visual inspection of outliers, with extremes being omitted from the regression analyses. To confirm whether or not $b$ values obtained in the linear regressions were significantly varied from the isometric value $(b=3)$, a t-test was applied, $t_{s}=(b-3) / \mathrm{s}_{\mathrm{b}}$ where $t_{s}$ is the t-test value, $b$ is the slope and $\mathrm{s}_{\mathrm{b}}$ is the standard error of the slope (b) (Sokal \& Rohlf 1987).

\section{CONDITION AND FORM FACTORS}

The Fulton's condition factor $\left(K_{F}\right)$ (Fulton 1904) was assessed using the formula $K_{F}=100 \times\left(W / L^{3}\right)$, where $W$ and $L$ are the BW $(\mathrm{g})$ and TL $(\mathrm{cm})$, respectively. The scaling factor of 100 was used to bring the $K_{F}$ close to unit. The relative condition factor $\left(K_{\mathrm{R}}\right)$ for each individual was estimated using the equation $K_{R}=W / a \times L^{b}$ (Le Cren 1951), where $W$ is the BW, $L$ is the TL and $a$ and $b$ are the LWR parameters. Additionally, the allometric condition factor $\left(K_{\mathrm{A}}\right)$ was calculated using the equation of Tesch (1968) $K_{\mathrm{A}}=W / L^{b}$, where $W$ is the BW, $L$ is the TL and $b$ is the LWR parameter. Furthermore, relative weight $\left(W_{R}\right)$ was estimated according to Froese (2006) as $W_{R}=\left(W / W_{S}\right) \times$ 100 , where $W$ is the weight of a particular individual and $W_{s}$ is the predicted standard weight for the same individual as calculated by $W_{s}=a L^{b}$ where, $a$ and $b$ values were obtained from the relationships between TL and BW. Prior to the regression analysis of $\ln \mathrm{BW}$ on $\ln \mathrm{TL}, \ln -\ln$ plots of length and weight values were performed for visual inspection of outliers, with extremes being excluded from the regression analyses.

The form factor $\left(a_{3.0}\right)$ of $L$. boga was calculated using the equation given by Froese (2006) as: $\left(a_{3.0}=\right.$ $\left.10^{\log a-S(b-3)}\right)$, where $a$ and $b$ are regression parameters of the length-weight relationships (LWRs) and $S$ is the regression slope of $\log a$ vs. $b$. During this study, a mean slope $S=$ -1.358 was used for estimating the form factor because information on LWRs is not available for this species for estimation of the regression (S) of $\ln a$ vs. $b$. 


\section{STATISTICAL ANALYSES}

Statistical analyses were performed using Microsoft ${ }^{\circledR}$ Excel-add-in-DDXL and GraphPad Prism 5. Normality tests of each group were conducted by visual assessment of histograms and box plots and confirmed using the Kolmogorov-Smirnov test. The Mann-Whitney $U$ test was used to compare the length-frequency distributions between the sexes. A Chi-square test was used to identify the sex-ratio divergence from the expected value of $1: 1$ (male: female). In the event the normality assumption was not met, the Mann Whiteny $U$-test was used to compare between two medians (TL, BW, $K_{F}, K_{A}$ and $K_{R}$ between sexes). Additionally, the median relative weight $\left(W_{R}\right)$ was compared with 100 according to Anderson and Neumann 1996. The Spearman rank test was used to correlate body measurements (TL, BW) and condition factors $\left(K_{F}\right)$. Moreover, the parameters $a$ and $b$ of the LWR between sexes were compared by the analysis of covariance (ANCOVA). All statistical analyses were considered significant at $5 \%$ $(p<0.05)$.

\section{RESULTS}

\section{LENGTH-FREQUENCY DISTRIBUTIONS}

A total of 211 specimens of L. boga were collected from the Padma River, northwestern Bangladesh during the study. Sample size, minimum and maximum lengths, minimum and maximum body weights, standard deviation (SD), 95\% confidence limit (CL) for male, female and combined gender are presented in Table 1 and Figure 1. The total length were ranged from 9.78 to $23.40 \mathrm{~cm}$ (mean $\pm \mathrm{SD}=$ $13.25 \pm 3.14$ ) for males and 10.30 to $27.50 \mathrm{~cm}$ (mean \pm
$\mathrm{SD}=17.11 \pm 4.56$ ) for females L. boga . The TL-frequency distribution showed that the males and females L. boga were not normality distributed (Kolmogorov-Smirnov test, $p<0.001)$ in the Padma River during this study. So, the Mann-Whitney $U$-test showed significant differences in the TL-frequency distributions of L. boga (Two tailed, Mann Whitney $\mathrm{U}=2587, p<0.001$ ) between males (median $=11.70 \mathrm{~cm}, 25 \%$ Percentile $=11.30 \mathrm{~cm}, 75 \%$ Percentile $=$ $14.80 \mathrm{~cm}$ ) and females (median $=15.00 \mathrm{~cm}, 25 \%$ Percentile $=14.50 \mathrm{~cm}, 75 \%$ Percentile $=21.70 \mathrm{~cm})$.

Furthermore, the BW of L. boga varied between 10.07 and $148.83 \mathrm{~g}($ mean $\pm \mathrm{SD}=28.61 \pm 29.00)$ in males and 10.00 and $276.10 \mathrm{~g}($ mean $\pm \mathrm{SD}=70.13 \pm 61.32)$ in females Nonetheless, the BW-frequency distribution showed that the males and females L. boga were not normality distributed (Kolmogorov-Smirnov test, $p<0.001$ ) in the Padma River. So, the Mann-Whitney U-test showed that $\mathrm{BW}$ of females $($ median $=15.81 \mathrm{~g}, 25 \%$ Percentile $=14.42$ $\mathrm{g}, 75 \%$ Percentile $=32.67 \mathrm{~g}$ ) was significantly higher $($ Two tailed, Mann-Whitney $\mathrm{U}=2328, p<0.001)$ than that for males $($ median $=35.46 \mathrm{~g}, 25 \%$ Percentile $=31.35 \mathrm{~g}, 75 \%$ Percentile $=123.20 \mathrm{~g}$ ).

\section{SEX RATIO}

Out of the 211 specimens ( male $=103$; female $=108$; male: female $=1: 1.05$ ) of $L$. boga collected in the Ganges River during this study, $49 \%$ were males and $51 \%$ were females. However, the overall sex ratio did not differ significantly from the expected value of $1: 1\left(\mathrm{df}=1, \chi^{2}=0.12, p<0.05\right)$. The TL dependent sex ratio of L. boga showed that males were dominant in the 9.00 to 12.99 TL groups, whereas females were dominant in the 13.00 to 27.99 TL groups (Table 2).

TABLE 1. Descriptive statistics on the length $(\mathrm{cm})$ and weight $(\mathrm{g})$ measurements of the L. boga (Hamilton 1822) in the Ganges River, northwestern Bangladesh

\begin{tabular}{|c|c|c|c|c|c|}
\hline Measurements & $\mathrm{n}$ & Min & Max & Mean \pm SD & $\mathrm{CL}_{95 \%}$ \\
\hline Male & 103 & & & & \\
\hline $\mathrm{TL}$ & & 9.78 & 23.40 & $13.25 \pm 3.14$ & $12.64-13.87$ \\
\hline $\mathrm{FL}$ & & 8.50 & 20.50 & $11.59 \pm 2.69$ & $11.07-12.12$ \\
\hline SL & & 7.70 & 18.50 & $10.54 \pm 2.51$ & $10.05-11.03$ \\
\hline BW & & 10.07 & 148.83 & $28.61 \pm 29.00$ & 22.94-34.27 \\
\hline Female & 108 & & & & \\
\hline $\mathrm{TL}$ & & 10.30 & 27.50 & $17.11 \pm 4.56$ & $16.24-17.98$ \\
\hline FL & & 9.00 & 24.00 & $14.89 \pm 3.90$ & $14.14-15.63$ \\
\hline SL & & 8.10 & 22.30 & $13.64 \pm 3.66$ & $12.95-14.34$ \\
\hline BW & & 10.00 & 276.10 & $70.13 \pm 61.32$ & $58.44-81.83$ \\
\hline Combined sex & 211 & & & & \\
\hline $\mathrm{TL}$ & & 9.78 & 27.50 & $15.23 \pm 4.37$ & $14.63-15.82$ \\
\hline FL & & 8.50 & 24.00 & $13.28 \pm 3.74$ & $12.77-13.79$ \\
\hline SL & & 7.70 & 22.30 & $12.13 \pm 3.51$ & $11.66-12.61$ \\
\hline BW & & 10.00 & 276.10 & $49.86 \pm 52.51$ & $42.74-56.99$ \\
\hline
\end{tabular}

$n$, sample size; Min, minimum; Max, maximum; SD, standard deviation; CL, confidence limit for mean values; TL, total length; FL, fork length; SL, standard length; BW, body weight 


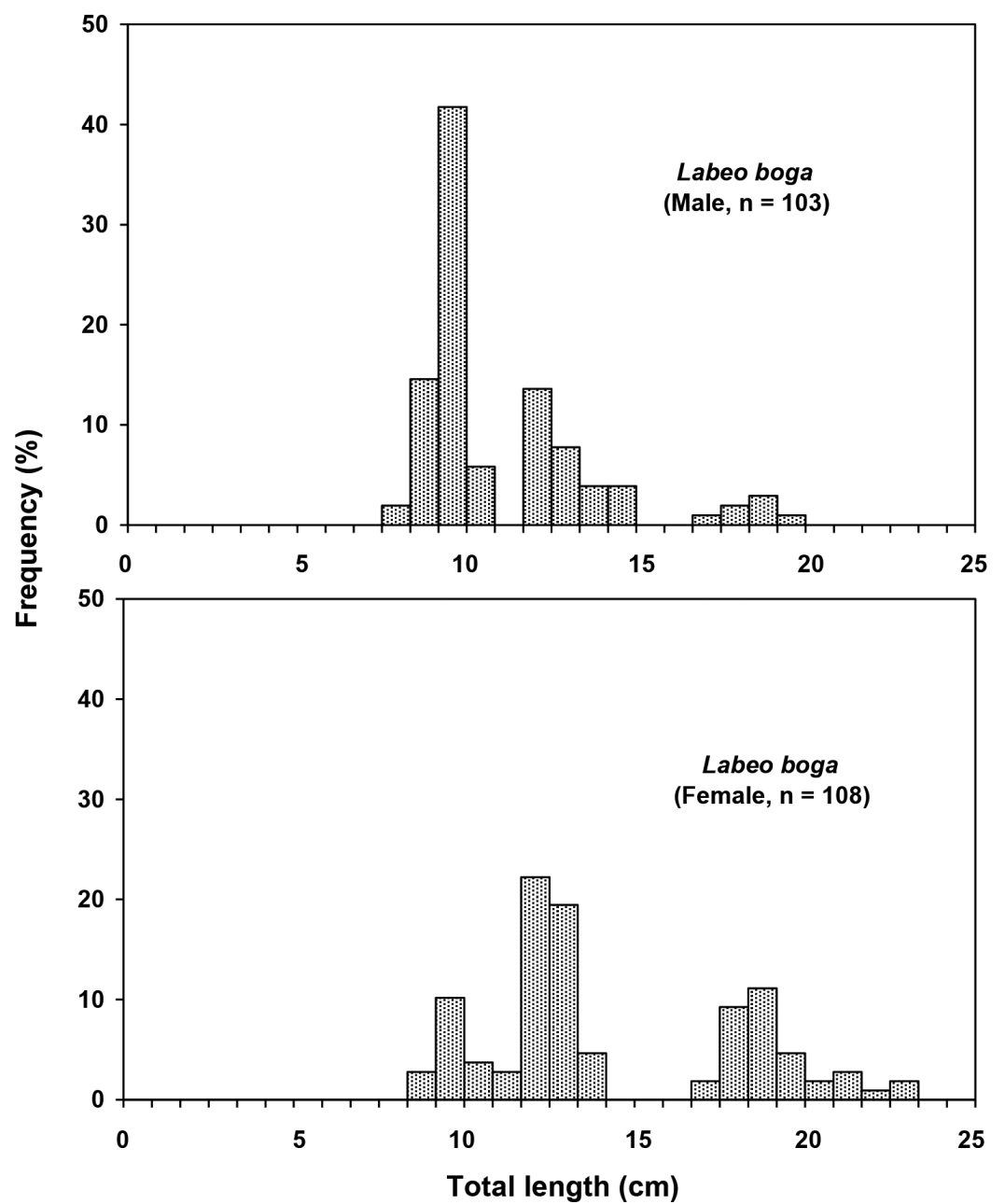

FIGURE 1. The length-frequency distribution of L. boga in the Ganges River, northwestern Bangladesh. Here, $n$ indicates the number of sample

TABLE 2. The sex ratio (male: female $=1: 1$ ) of the total length dependent for L. boga in the Ganges River, northwestern Bangladesh

\begin{tabular}{|c|c|c|c|c|c|c|}
\hline \multirow{2}{*}{$\begin{array}{l}\text { Length class } \\
\quad(\mathrm{TL}, \mathrm{cm})\end{array}$} & \multicolumn{3}{|c|}{ Number of specimens } & \multirow{2}{*}{$\begin{array}{c}\text { Sex ratio } \\
\text { (Male/ Female) }\end{array}$} & \multirow{2}{*}{$\chi^{2}(\mathrm{df}=1)$} & \multirow{2}{*}{ Significance } \\
\hline & Male & Female & Total & & & \\
\hline $9.00-9.99$ & 2 & 0 & 2 & - & 2.00 & ns \\
\hline $10.00-10.99$ & 15 & 3 & 18 & $1: 0.20$ & 8.00 & $* *$ \\
\hline $11.00-11.99$ & 43 & 11 & 54 & $1: 0.26$ & 18.96 & $* * *$ \\
\hline $12.00-12.99$ & 6 & 4 & 10 & $1: 0.67$ & 0.40 & $\mathrm{~ns}$ \\
\hline $13.00-13.99$ & 0 & 3 & 3 & - & 3.00 & ns \\
\hline $14.00-14.99$ & 14 & 24 & 38 & $1: 1.71$ & 2.63 & ns \\
\hline $15.00-15.99$ & 8 & 21 & 29 & $1: 2.63$ & 5.83 & $*$ \\
\hline $16.00-16.99$ & 4 & 5 & 9 & $1: 1.25$ & 0.11 & ns \\
\hline $17.00-17.99$ & 4 & 0 & 4 & - & 4.00 & $*$ \\
\hline $18.00-18.99$ & 0 & 0 & 0 & - & 0.00 & - \\
\hline $19.00-20.99$ & 0 & 0 & 0 & - & 0.00 & - \\
\hline $20.00-20.99$ & 1 & 2 & 3 & $1: 2.00$ & 0.33 & $* *$ \\
\hline $21.00-21.99$ & 2 & 10 & 12 & $1: 5.00$ & 5.33 & $*$ \\
\hline $22.00-22.99$ & 3 & 12 & 15 & $1: 4.00$ & 5.40 & $*$ \\
\hline $23.00-23.99$ & 1 & 5 & 6 & $1: 5.00$ & 2.67 & ns \\
\hline $24.00-24.99$ & 0 & 2 & 2 & - & 2.00 & ns \\
\hline $25.00-25.99$ & 0 & 3 & 3 & - & 3.00 & ns \\
\hline $26.00-26.99$ & 0 & 1 & 1 & - & 1.00 & ns \\
\hline $27.00-27.99$ & 0 & 2 & 2 & & 2.00 & ns \\
\hline Overall & 103 & 108 & 211 & $1: 1.05$ & 0.12 & ns \\
\hline
\end{tabular}

$\mathrm{ns}$, not significant; *, significant at $5 \%$ level $\left(\chi_{\mathrm{t} 1,0.05}^{2}=3.84\right)$, **, $1 \%$ level $\left(\chi_{\mathrm{t} 1,0.01}^{2}=6.63\right)$ and $* * *, 0.1 \%$ level $\left(\chi_{\mathrm{t} 1,0.001}^{2}=10.83\right)$ 


\section{LENGTH-WEIGHT RELATIONSHIPS}

The regression parameter $b$ values for male, female and combined gender L. boga were 3.008, 3.114 and 3.133, respectively. The calculated $b$ for the LWR indicated isometric growth $(\sim 3.00)$ in males, females and combined gender L. boga in the Padma River. However, there was significant differences in the intercepts (ANCOVA, $\mathrm{F}=8.38, \mathrm{df}=208, p<0.001)$ but not in the slopes (ANCOVA, $\mathrm{F}=1.35$, $\mathrm{df}=207, p=0.247$ ) between the sexes. Sample sizes $(n)$, regression parameters and $95 \%$ confidence intervals for $a$ and $b$ of the LWR, coefficients of determination $\left(r^{2}\right)$ and growth type of L. boga are given in Table 3 and in Figure 2. Moreover, plots of predicted body weight for respective observed length as calculated from the composite of length-weight regression (Rypel $\&$ Richter 2008) are shown in Figure 3. The regression models showed that there were no significant differences between observation and prediction growth patterns in males and females of L. boga (ANCOVA, $p>0.05$ ).

\section{FULTON'S CONDITION FACTOR $\left(K_{F}\right)$}

The $K_{F}$ ranged from 0.70 to 1.35 (mean $\pm \mathrm{SD}=1.02$ \pm 0.14 ) in males and 0.73 to 1.51 (mean $\pm \mathrm{SD}=1.11$ \pm 0.17 ) in females (Table 4). The Spearman rank test

TABLE 3. Descriptive statistics and estimated parameters of the length-weight relationships $\left(B W=a \times T L^{b}\right)$ and form factor $\left(a_{3,0}=10^{\log a-S(b-3)}\right)$ of L. boga (Hamilton 1822) in the Ganges River, northwestern Bangladesh

\begin{tabular}{lcccccccc}
\hline Sex & $a$ & $b$ & $\mathrm{CL}_{95 \%}$ of $\mathrm{a}$ & $\mathrm{CL}_{95 \%}$ of $\mathrm{b}$ & $r^{2}$ & $t_{s}$ & $\mathrm{GT}$ & $\left(\mathrm{a}_{3.0}\right)$ \\
\hline $\begin{array}{l}\text { Male } \\
(n=103)\end{array}$ & 0.0099 & 3.008 & $0.0071-0.0138$ & $2.878-3.139$ & 0.954 & 0.05 & $\mathrm{I}$ & 0.0102 \\
$\begin{array}{l}\text { Female } \\
(n=108)\end{array}$ & 0.0080 & 3.114 & $0.0057-0.0112$ & $2.994-3.234$ & 0.962 & 0.67 & $\mathrm{I}$ & 0.0113 \\
$\begin{array}{l}\text { Common gender } \\
(n=211)\end{array}$ & 0.0074 & 3.133 & $0.0074-0.0091$ & $3.055-3.211$ & 0.967 & 1.23 & $\mathrm{I}$ & 0.0111 \\
\hline
\end{tabular}

$n$, sample size; $B W$, body weight; $T L$, total length; $a$, intercept; $b$, slope; CL, confidence limits; $r^{2}$, coefficient of determination; GT, growth type (I, isometric growth based on: $\mathrm{t}_{\mathrm{s}}=(b-3) / \mathrm{s}_{\mathrm{b}}$, where $\mathrm{t}_{\mathrm{s}}$ is the $t$-test value, $b$ the slope and $\mathrm{s}_{\mathrm{b}}$ the standard error of the slope $(b) ; a_{3.0}$, form factor

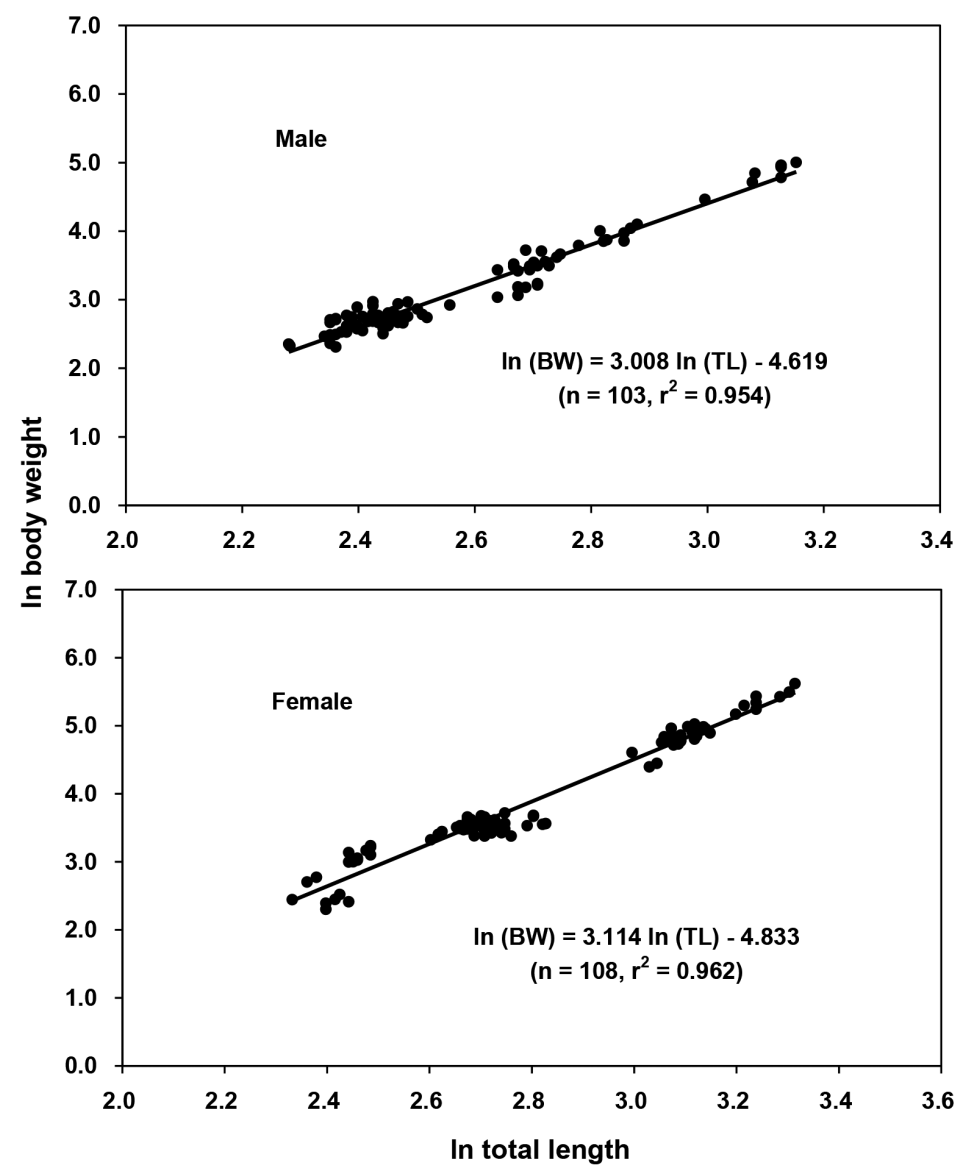

FIGURE 2. Relationships between ln total length (ln TL) and ln body weight (ln BW) of L. boga (Hamilton 1822) in the Ganges River, northwestern Bangladesh 


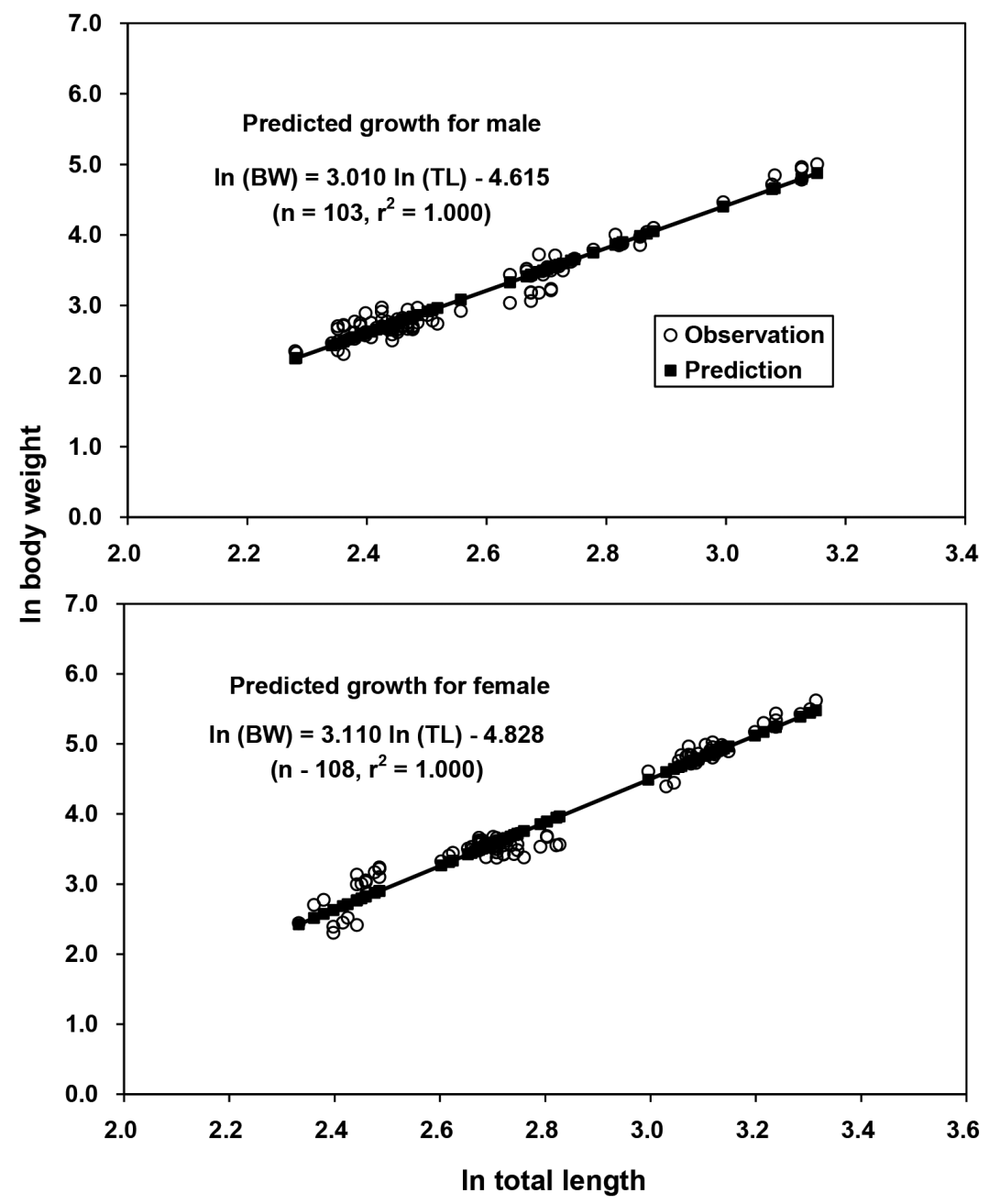

FIGURE 3. Predicted growth for L. boga (Hamilton 1822) in the Ganges River, northwestern Bangladesh

TABLE 4. Condition factors $\left(K_{F}, K_{R}, K_{R}\right.$ and $\left.W_{R}\right)$ of the L. bogas (Hamilton 1822) in the Ganges River, northwestern Bangladesh

\begin{tabular}{|c|c|c|c|c|c|}
\hline Condition factor & $n$ & Min & Max & Mean \pm SD & $\mathrm{CL}_{95 \%}$ \\
\hline Male & 103 & & & & \\
\hline$K_{F}$ & & 0.70 & 1.35 & $1.02 \pm 0.14$ & 0.99-1.04 \\
\hline$K_{R}$ & & 0.69 & 1.33 & $1.00 \pm 0.14$ & 0.97-1.03 \\
\hline$K_{A}$ & & 0.0068 & 0.0132 & $0.0099 \pm 0.0014$ & $0.0096-0.0102$ \\
\hline$W_{R}^{A}$ & & 69.07 & 133.37 & $99.98 \pm 13.69$ & 97.31-102.66 \\
\hline Female & 108 & & & & \\
\hline$K_{F}$ & & 0.73 & 1.51 & $1.11 \pm 0.17$ & $1.08-1.14$ \\
\hline$K_{R}^{F}$ & & 0.67 & 1.44 & $1.02 \pm 0.16$ & $0.99-1.05$ \\
\hline$K_{A}$ & & 0.0053 & 0.0115 & $0.0082 \pm 0.0013$ & $0.01-0.01$ \\
\hline$W_{R}^{A}$ & & 66.79 & 144.19 & $101.95 \pm 16.07$ & $98.88-105.01$ \\
\hline \multicolumn{6}{|l|}{ Combined sex } \\
\hline$K_{F}$ & 211 & 0.70 & 1.51 & $1.06 \pm 0.16$ & $1.04-1.09$ \\
\hline$K_{R}$ & & 0.67 & 1.48 & $1.01 \pm 0.15$ & 0.99- 1.03 \\
\hline$K_{A}^{K}$ & & 0.0050 & 0.0110 & $0.0075 \pm 0.0011$ & $0.0073-0.0077$ \\
\hline$W_{R}^{A}$ & & 67.04 & 148.45 & $101.37 \pm 15.46$ & $99.27-103.47$ \\
\hline
\end{tabular}

( $n$, sample size; Min, minimum; Max, maximum; SD, standard deviation; CL, confidence limit for mean values; $K_{F}$, Fulton's condition factor; $K_{R}$, relative condition factor; $K_{A}$, allometric condition factor; $W_{R}$, relative weight) 
showed that $K_{F}$ was not correlated with TL for males (Two tailed, $r_{s}=-0.150,95 \%$ CL of $r_{s}=-0.339$ to -0.051 , $p=0.131$ ) and females (Two tailed, $\mathrm{r}_{\mathrm{s}}=0.045,95 \% \mathrm{CL}$ of $r_{s}=-0.151$ to $\left.0.238, p=0.641\right)$, but, there was strong correlation between $K_{F}$ and BW for males (Spearman rank test, Two tailed, $r_{s}=0.256,95 \% \mathrm{CL}$ of $\mathrm{r}_{\mathrm{s}}=0.060$ to $0.433, p=0.009$ ) and females (Spearman rank test, Two tailed, $r_{s}=0.297,95 \%$ CL of $r_{s}=0.109$ to 0.465 , $p=0.002)$ in the Padma River. The Mann-Whitney U-test showed that Fulton's condition factor of females (median $=1.12,25 \%$ Percentile $=1.03,75 \%$ Percentile $=1.22$ ) was significantly higher (Two tailed, Mann-Whitney $\mathrm{U}=$ $3565, p<0.001)$ than that for males (median $=1.01,25 \%$ Percentile $=0.94,75 \%$ Percentile $=1.09$ ) .

\section{RELATIVE CONDITION FACTOR $\left(K_{R}\right)$}

The $K_{R}$ for males and females $L$. boga varied between 0.69 and 1.33 (mean $\pm \mathrm{SD}=1.00 \pm 0.14$ ) and 0.67 and 1.44 (mean $\pm \mathrm{SD}=1.02 \pm 0.16$ ), respectively (Table 4$)$. The Mann-Whitney U-test showed that $K_{R}$ was not significantly difference (Two tailed, Mann-Whitney $\mathrm{U}=4925, p=0.151$ ) between males $($ median $=0.99,25 \%$ Percentile $=0.92$, $75 \%$ Percentile $=1.07)$ and females (median $=1.02,25 \%$ Percentile $=0.94,75 \%$ Percentile $=1.11)$.

\section{ALLOMETRIC CONDITION FACTOR $\left(K_{A}\right)$}

The $K_{A}$ ranged from 0.0068 to 0.0132 (mean $\pm \mathrm{SD}=$ $0.0099 \pm 0.0014$ ) for males and 0.0053 to 0.0115 (mean \pm $\mathrm{SD}=0.0082 \pm 0.0013$ ) for females (Table 4). The MannWhitney U-test showed that $K_{A}$ of males (median $=0.0098$, $25 \%$ Percentile $=0.0091,75 \%$ Percentile $=0.011)$ was significantly higher (Two tailed, Mann Whitney $\mathrm{U}=1879$, $p<0.001$ ) than that for females (median $=0.0082,25 \%$ Percentile $=0.0075,75 \%$ Percentile $=0.0089)$.

\section{RELATIVE WEIGHT $\left(W_{R}\right)$}

The $W_{R}$ for male and female L. boga ranged from 69.07 to 133.37 (mean $\pm \mathrm{SD}=99.98 \pm 13.69$ ) and 66.79 to 144.19 $($ mean $\pm \mathrm{SD}=101.95 \pm 16.07)$, respectively (Table 4). The Wilcoxon signed rank test showed that the $W_{R}$ (actual median $=98.87$ for males and 102.00 for females) did not differ from 100 for males (Two tailed, $p=0.709$ ) and females (Two tailed, $p=0.139$ ) in this study, indicating the habitat was still in good condition for L. boga. Additionally, the results showed that $W_{R}$ did not differ significantly between sexes (Two tailed, Mann Whitney $U=4964$, $p=0.178$ ) in the Padma River.

\section{FORM FACTOR $\left(A_{30}\right)$}

Form factor of male and female L. boga was calculated as 0.0102 and 0.0113 , respectively (Table 3 ).

\section{DISCUSSION}

\section{LENGTH-FREQUENCY DISTRIBUTION}

This study recorded the minimum size of L. boga as $9.78 \mathrm{~cm}$ TL during the sampling period indicating either the absence of small sized fishes $(<9.78 \mathrm{~cm}$ TL) in the populations or selectivity of the fishing gears (Hossain et al. 2012c). In contrast, the maximum size of L. boga found during present study within the Padma River ecosystem was $27.50 \mathrm{~cm} \mathrm{TL}$, which is less than the maximum reported value of $30 \mathrm{~cm}$ in Krishna River, Karnataka, India (Chandrashekhariah 2000). Again, the maximum body weight of L. boga recorded in this study was $276.10 \mathrm{~g}$ which is much less than that recorded by Parvin et al. (2011) as $450 \mathrm{~g}$ in Rajshahi while studying the sex ratio and fecundity of this species. The reduction in the recorded maximum sizes of individuals of L. boga in the Padma River in this study might be attributed either to the absence of larger-sized individuals in the populations in fishing grounds (Hossain et al. 2012c). In addition, water temperature can be directly related to biological production rates and food availability along with nekton and plankton species composition, both of which influence fish growth. Furthermore, numerous types of fishing gear with various mesh sizes were used by the traditional fishers leading to the selectivity of target species which may greatly influence the size distribution of the individuals caught resulting in highly biased estimations of the various population parameters including the maximum size (Hossain et al. 2012d).

\section{SEX RATIO}

Avşar (1998) pointed out that in a typical population, female to male ratio will vary between $1: 1$ and 1:1.3. Though departure from a 1:1 sex ratio is not expected for most aquatic (fin- and shellfish) species, some finfish and prawn populations may show a strong bias in this ratio (Hossain et al. 2012c). In the present study, the male and female sex ratio was 1:1.05. The overall sex ratio did not differ significantly from the expected value of $1: 1$. However, Parvin et al. (2011) reported the male to female sex ratio of L. boga as 1:2.27 in Rajshahi which is different from the findings of this study. Such differences could be from various causes, including thermal influences on sex determination (Conover \& Kynard 1981), selective mortality by sex through differential predation and divergent sexual behavior, growth rate, or longevity expectation (Schultz 1996) and variant climate and regional conditions (Avşar 1998). Furthermore, size dependent sex ratio divergence is also evident in the result which may be due to different growth between sexes (Rahman et al. 2012a). 


\section{LENGTH-WEIGHT RELATIONSHIPS}

In this study, the $b$ values for male, female and combined gender L. boga were found as 3.008, 3.114 and 3.133, respectively indicating isometric growth of L. boga in the Padma River i.e., the body increases in all dimensions in the same proportion to growth (Jobling 2008). However, Pervin and Mortuza (2008) estimated the $b$ values of male, female and combined gender L. boga as 2.975, 3.289 and 3.108 , respectively, though they did not specified any definite habitat.

It is widely recognized that a number of factors are known to influence the length-weight relationship in fish, including growth phase, sex, seasons, food (quantity, quality and size), stage of maturity and health and general fish condition, preservation techniques and differences in the observed length ranges of the specimen caught (Hossain et al. 2006, 2012e; Ricker 1973; Tesch 1971), all of which were not accounted in the present study. Furthermore, the regression models show that there were no significant differences between observation and prediction growth patterns in L. boga from the Padma River, Nw Bangladesh. Since the sample of L. boga were collected over an extended period of time, this data did not represent any particular season, so it should be treated only as mean-annual values for comparative purposes (Hossain et al. 2012f).

\section{CONDITION FACTORS}

Condition factor is an index reflecting interactions between biotic and abiotic factors in the physiological condition of the fishes that show the well-being of the population during various life cycle stages (Angelescu et al. 1958). In order to evaluate the general health and productivity of L. boga, several condition factors including Fulton's, relative, allometric and relative weights were calculated during this study. The results showed that the Fulton's condition factor was significantly higher in females than in males though the relative condition factor showed no significant differences between sexes. However, no references dealing with the condition factors of the L. boga are available in the Padma River, preventing the comparison with previous results from the same population.

Furthermore, the relative weight showed no significant differences from 100 for males and females L. boga in this study showing the prevalence of good condition in the habitat for this fish. However, L. boga is categorized as critically endangered in Bangladeshi waters by IUCN Bangladesh (2000) which might be due to various causes other than water quality (Rahman et al. 2012b). Nonetheless, this information would assist for urgent detection of any long-term deterioration in condition that may have occurred. However, there is no reference dealing with the relative weight of L. boga available in literature restraining the comparison of this findings with previous results and will form the basis for further such studies.

\section{FORM FACTOR $\left(a_{3.0}\right)$}

Only a few studies on form factor of fish are available in Bangladeshi waters (Hossain et al. 2014, 2013a, 2012b; Rahman et al. 2012b). According to the ranges given by Froese (2006), the values of form factor of L. boga found in this study closely matches to the range given for fusiform fishes. However, due to the overlap of ranges, it is not conclusive to assign body shape based only on the form factor (Froese 2006). Nonetheless, there is no reference available concerning the form factor of this species in the world so this is the first such study on this regard for $L$. boga which will be helpful for future studies.

\section{CONCLUSION}

The results of this study would certainly be an effective tool for fishery biologists, managers and conservationists to initiate early management strategies and regulations for the sustainable conservation of the remaining stocks of this species in the Padma River and surrounding ecosystems. Also, this study would be useful for further studies on the population assessment of the species in Bangladeshi waters and neighboring countries.

\section{ACKNOWLEDGEMENTS}

We would like to express our gratitude to local fishermen (Rajshahi, Bangladesh) for their assistance during sample collection, the Department of Fisheries, University of Rajshahi (Bangladesh) for laboratory facilities and anonymous referee for their useful and constructive comments. Also, we like to acknowledge TWAS (GRA No.: 14-028 RG/BIO/AS_I-UNESCO FR: 324028574) for supports.

\section{REFERENCES}

Anderson, R.O. \& Neumann, R.M. 1996. Length, weight and associated structure indices. In: Fisheries Techniques. 2nd ed., edited by Murphy, B.R. \& Willis, D.W. Bethesda, MD: American Fisheries Society. pp. 447-482.

Angelescu, V., Gneri, F.S. \& Nani, A. 1958. La merluza del mar argentine (biologia e taxonomia). Secr. Mar. Serv. Hidrog. Nav. Publico, H1004. pp. 1-224.

Avşar, D. 1998. Fisheries biology and population dynamics. University of Çukurova, Faculty of Fisheries, Adana, Turkey, pp. 303 (in Turkish - unpublished).

Chandrashekhariah, H.N., Rahman, M.F. \& Lakshmi Raghavan, S. 2000. Status of fish fauna in Karnataka. pp. 98-135. In Endemic Fish Diversity of Western Ghats, edited by Ponniah, A.G. \& Gopalakrishnan A. NBFGR-NATP publication. National Bureau of Fish Genetic Resources, Lucknow, U.P., India. 1, p. 347.

Conover, D.O. \& Kynard, B.O. 1981. Environmental sex determination: Interaction of temperature and genotype in a fish. Science 213: 577-579.

Dahanukar, N. 2010. Labeo boga. In IUCN 2012. IUCN Red List of Threatened Species. Version 2012.2. <www.iucnredlist. org>. Accessed on 19 December 2012. 
Froese, R. 2006. Cube law, condition factor and weight length relationship: History, meta-analysis and recommendations. Journal of Applied Ichthyology 22: 241-253.

Fulton, T.W. 1904. The rate of growth of fishes. Twenty-second Annual Report. Part III. Fisheries Board of Scotland, Edinburgh. pp. 141-241.

Gerritsen, H.D. \& McGrath, D. 2007. Significant differences in the length-weight relationships of neighbouring stocks can result in biased biomass estimates: Examples of haddock (Melanogrammus aeglefi nus, L.) and whiting (Merlangius merlangus, L.). Fisheries Research 85: 106-111.

Hossain, M.Y., Rahman, M.M., Ahamed, F., Ahmed, Z.F. \& Ohtomi, J. 2014. Length-weight and length-length relationships and form factor of three threatened fishes from the Ganges River (NW Bangladesh). Journal of Applied Ichthyology 30(1): 221-224.

Hossain, M.Y., Khatun, M.M., Jasmine, S., Rahman, M.M., Jewel, M.A.S. \& Ohtomi, J. 2013a. Life-history traits of the threatened freshwater fish Cirrhinus reba (Hamilton 1822) (Cypriniformes: Cyprinidae) in the Ganges River, Northwestern Bangladesh. Sains Malaysiana 42(9): 12191229.

Hossain, M.Y., Jewel, M.A.S., Rahman, M.M., Haque,A.B.M.M. \& Ohtomi. J. 2013b. Life-history traits of the freshwater garfish Xenentodon cancila (Hamilton, 1822) (Belonidae) in the Ganges River, Northwestern Bangladesh. Sains Malaysiana 42(9): 1207-1218.

Hossain, M.Y., Rahman, M.M., Jewel, M.A.S., Hossain, M.A., Ahamed, F., Tumpa, A.S., Abdallah, E.M. \& Ohtomi, J. $2013 \mathrm{c}$. Life-history traits of the critically endangered catfish Eutropiichthys vacha (Hamilton, 1822) in the Jamuan (Brahmaputra River distributary) River, northern Bangladesh. Sains Malaysiana 42(3): 265-277.

Hossain, M.Y., Rahman, M.M., Fulanda, B., Jewel, M.A.S., Ahamed, F. \& Ohtomi, J. 2012a. Length-weight and lengthlength relationships of five threatened fishes from the Jamuna (Brahmaputra River distributary) River, northern Bangladesh. Journal of Applied Ichthyology 28(2): 275-277.

Hossain, M.Y., Rahman, M.M., Jewel, M.A.S., Ahmed, Z.F., Ahamed, F., Fulanda, B. \& Ohtomi, J. 2012b. Conditionsand form-factor of the five threatened fishes from the Jamuna (Brahmaputra River Distributary) River, northern Bangladesh. Sains Malaysiana 41(6): 671-678.

Hossain, M.Y., Ohtomi, J., Ahmed, J., Jasmine, S. \& Vadas, R.L. 2012c. Life-history traits of the Monsoon River prawn Macrobrachium malcolmsonii (Milne-Edwards, 1844) (Palaemonidae) in the Ganges (Padma) River, northwestern Bangladesh. Journal of Freshwater Ecology 27(1): 131-142.

Hossain, M.Y., Jewel, M.A.S., Nahar, L., Rahman, M.M., Naif, A. \& Ohtomi, J. 2012d. Gonadosomatic index-based size at first sexual maturity of the catfish Eutropiichthys vacha (Hamilton, 1822) in the Ganges River (NW Bangladesh). Journal of Applied Ichthyology 28(4): 601-605.

Hossain, M.Y., Rahman, M.M. \& Abdallah, E.M. 2012e. Relationships between body size, weight, condition and fecundity of the threatened fish Puntius ticto (Hamilton, $1822)$ in the Ganges River, northwestern Bangladesh. Sains Malaysiana 41(7): 803-814.

Hossain, M.Y., Rahman, M.M., Miranda, R., Leunda, P.M., Oscoz, J., Jewel, M.A.S., Naif, A. \& Ohtomi, J. 2012f. Size at first sexual maturity, fecundity, length-weight and lengthlength relationships of Puntius sophore (Cyprinidae) in Bangladeshi waters. Journal of Applied Ichthyology 28(5): 818-822.
Hossain, M.Y., Ohtomi, J. \& Ahmed, Z.F. 2009a. Morphometric, meristic characteristics and conservation of the threatened fish, Puntius sarana (Hamilton, 1822) (Cyprinidae) in the Ganges River, northwestern Bangladesh. Turkish Journal of Fisheries and Aquatic Sciences 9(2): 223-225.

Hossain, M.Y., Ohtomi, J., Ahmed, Z.F., Jasmine, S. \& Ibrahim, A.H.M. 2009b. Length-weight and morphometric relationships of the tank goby Glossogobius giuris (Perciformes: Gobiidae) in the Ganges of the northwestern Bangladesh. Asian Fisheries Science 22(3): 961-969.

Hossain, M.Y., Ahmed, Z.F., Leunda, P.M., Jasmine, S., Oscoz, J., Miranda, R. \& Ohtomi, J. 2006. Condition, length-weight and length-length relationships of the Asian striped catfish Mystus vittatus (Bloch, 1794) (Siluriformes: Bagridae) in the Mathabhanga River, southwestern Bangladesh. Journal of Applied Ichthyology 22(4): 304-307.

IUCN Bangladesh. 2000. Red book of threatened fishes of Bangladesh. In The World Conservation Union, edited by Mahmud-ul-Ameen, Md. Anwarul Islam \& Ainun Nishat xi, p.116.

Jobling, M. 2008. Environmental factors and rates of development and growth. In Handbook of Fish Biology and Fisheries, Vol. 1: Fish Biology, edited by Hart, P.J. \& Reynolds, J.D. Oxford: Blackwell Publishing Ltd. pp. 97-122.

King, M. 2007. Fisheries Biology, Assessment and Management. 2nd ed. Oxford: Blackwell Scientific Publications. pp. 1-381.

Koutrakis, E.T.\& Tsikliras, A.C. 2003. Length-weight relationships of fishes from three northern Aegean estuarine systems (Greece). Journal of Applied Ichthyology 19(4): 258-260.

Le Cren, E.D. 1951. The length-weight relationship and seasonal cycle in gonad weight and condition in the perch (Perca fluviatilis). Journal of Animal Ecology 20: 201-219.

Menon, A.G.K. 1999. Check list - fresh water fishes of India Rec. Zool. Surv. India, Misc. Publ., Occas. Pap. No. 175. pp. 366.

Parvin, M.R., Al-Misned, F.A. \& Mortuza, M.G. 2011. The fecundity and sex ratio of Labeo boga (Hamilton) (Cypriniformes: Cyprinidae) of Rajshahi, Bangladesh. Continental Journal of Fisheries and Aquatic Science 5(3): 19-21.

Pervin, M.R. \& Mortuza, M.G. 2008. Length-weight relationship and condition factor of fresh water fish, Labeo boga (Hamilton) (Cypriniformes: Cyprinidae). University Journal of Zoology, Rajshahi University 27: 97-98.

Rahman, A.K.A. 2005. Freshwater Fishes of Bangladesh. 2nd ed. Zoological Society of Bangladesh, Department of Zoology, University of Dhaka, Dhaka-1000, pp. 1-263.

Rahman, M.M., Hossain, M.Y., Hossain, M.A., Ahamed, F. \& Ohtomi, J. 2012a. Sex ratio, length-frequency distributions and morphometric relationships of length-length and length-weight for Spiny eel, Macrognathus aculeatus in the Ganges River, NW Bangladesh. World Journal of Zoology 7(4): 338-347.

Rahman, M.M., Hossain, M.Y., Jewel, M.A.S., Rahman, M.M., Jasmine, S., Abdallah, E.M. \& Ohtomi, J. 2012b. Population structure, length-weight and length-length relationships and condition and form-factor of the pool barb Puntius sophore (Hamilton, 1822) (Cyprinidae) from the Chalan Beel, northcentral Bangladesh. Sains Malaysiana 41(7): 795-802. 
Ricker, W.E. 1973. Linear regression in fisheries research. Journal of Fisheries Research Board of Canada 30: 409434.

Rypel, A.L. \& Richter, T.J. 2008. Empirical percentile standard weight equation for the blacktail redhorse. North American Journal of Fisheries Management 28: 1843-1846.

Schultz, H. 1996. Drastic decline of the proportion of males in the roach (Rutilus rutilus L.) of Bautzen Reservoir (Saxony, Germany): Result of direct and indirect effects of biomanipulation. Limmologica 26: 153-164.

Sokal, R.R.\& Rohlf, F.J. 1987. Introduction to Biostatistics. 2nd ed. New York: Freeman Publication.

Tesch, F.W. 1971. Age and growth. In Methods for Assessment of Fish Production in Fresh Waters. Ricker, W.E. Oxford: Blackwell Scientific Publications. pp. 99-130.
Tesch, F.W. 1968. Age and growth. In Methods for Assessment of Fish Production in Fresh Waters, edited by Ricker, W.E. Oxford: Blackwell Scientific Publications. pp. 93-123.

Department of Fisheries, Faculty of Agriculture University of Rajshahi, Rajshahi 6205

Bangladesh

*Corresponding author; email: yeamin2222@yahoo.com

Received: 27 February 2013

Accepted: 14 June 2014 